\title{
PENGARUH PRODUKTIVITAS TERHADAP BIAYA PEKERJAAN FABRIKASI BESI PROYEK INDONESIA 1 DENGAN METODE CREW BALANCE CHART
}

\author{
Yulius Kelvin $^{1}$ dan Hendrik Sulistio ${ }^{2}$ \\ ${ }^{1}$ Program Studi Sarjana Teknik Sipil, Universitas Tarumanagara, Jl. Letjen S.Parman No.1 Jakarta \\ Email:yuliuskelvin@yahoo.com \\ ${ }^{2}$ Program Studi Doktor Teknik Sipil, Universitas Tarumanagara, Jl. Letjen S.Parman No.1 Jakarta \\ Email: hendriks@ft.untar.ac.id
}

\begin{abstract}
ABSTRAK
Produktivitas merupakan faktor yang mempengaruhi berbagai macam hal dalam pelaksanaan proyek konstruksi. Pada proyek konstruksi banyak ditemukan pemborosan biaya dikarenakan rendahnya produktivitas dari pekerja, yang cenderung disebabkan oleh banyaknya waktu tidak produktif yang terjadi selama pelaksanaan pekerjaan. Untuk memperoleh data produktivitas, proses pelaksanaan suatu pekerjaan akan didata dan ditampilkan dalam bentuk diagram yang disebut Crew Balance Chart (CBC). Besaran produktivitas ini kemudian akan ditingkatkan untuk membandingkan biaya dari pekerjaan fabrikasi tulangan pada proyek Indonesia 1 dalam kondisi real dan optimal serta menghitung kerugian yang diperoleh akibat rendahnya produktivitas. Penelitian ini akan menggunakan metode observasi dengan video camera dan wawancara untuk memperoleh data-data yang dibutuhkan. Data yang diambil dengan cara merekam dan mencatat waktu produktif dan waktu tidak produktif dari pekerjaan fabrikasi tulangan. Waktu produktif dan tidak produktif ini akan diproses dan dihitung dengan matematika sederhana untuk mendapatkan waktu produktivitas tenaga kerja dan mengetahui koefisien produktivitas tenaga kerja. Berdasarkan hasil penelitian, dapat dikatakan bahwa produktivitas para pekerja yang terlibat kurang baik. Hal ini terbukti dari rendahnya waktu produktif para pekerja selama bekerja di lapangan, di mana waktu produktif dari para pekerja berkisar di angka 50\%. Hal ini berimbas pada timbulnya pemborosan biaya pekerjaan fabrikasi tulangan. Pekerjaan yang seharusnya hanya memakan biaya sebesar Rp 287.799.030,30, justru mengeluarkan biaya sebesar Rp 301.564.489,40. Akibatnya, timbul kerugian akibat kelebihan biaya pekerjaan fabrikasi tulangan ini, yaitu sebesar Rp 13.765.459,14.
\end{abstract}

Kata kunci : Produktivitas Tenaga Kerja, Biaya, Crew Balance Chart

\section{PENDAHULUAN}

\section{Latar belakang}

Setiap peralatan dan tenaga kerja memiliki kemampuan atau produktivitasnya masing-masing dalam mengerjakan suatu pekerjaan. Produktivitas ini menjadi faktor yang mempengaruhi berbagai macam hal dalam pelaksanaan proyek konstruksi, di antaranya biaya pelaksanaan proyek. Pengaruhnya ke dalam suatu pekerjaan dapat dilihat dari adanya delay atau jeda waktu dalam pelaksanaan pekerjaan.

Biaya merupakan salah satu hal yang penting dan berpengaruh dalam kesuksesan pelaksanaan suatu proyek konstruksi. Biaya pelaksanaan proyek sangat bergantung terhadap produktivitas peralatan dan tenaga kerja. Semakin tinggi produktivitas, maka semakin kecil pula kemungkinan terjadinya kelebihan biaya pelaksanaan proyek, dan begitu pula dengan sebaliknya. Pada proyek konstruksi banyak ditemukan kelebihan biaya dikarenakan rendahnya produktivitas dari pekerja. Produktivitas yang rendah ini cenderung disebabkan oleh banyaknya waktu tidak produktif yang terjadi selama pelaksanaan pekerjaan. Padahal, upah pekerja yang dibayarkan kepada tiap pekerja yang sudah ada belum tentu sesuai dengan produktivitas para pekerja selama di lapangan. Oleh karena itu, produktivitas dari tenaga kerja dan peralatan ini perlu ditinjau ulang kembali agar dapat dimaksimalkan, sehingga hasilnya sesuai dengan yang diharapkan.

Untuk memperoleh data produktivitas, proses pelaksanaan suatu pekerjaan akan didata dan ditampilkan dalam bentuk diagram yang disebut Crew Balance Chart $(C B C)$. Setelah diagram Crew Balance Chart ini selesai dibuat, maka besar produktivitas dari tenaga kerja yang terlibat dalam pekerjaan tersebut dapat dihitung. Besaran produktivitas yang didapat dari diagram Crew Balance Chart ini kemudian akan ditingkatkan untuk membandingkan biaya dari pekerjaan fabrikasi tulangan pada proyek Indonesia 1 dalam kondisi real dan optimal serta menghitung kerugian yang diperoleh akibat rendahnya produktivitas para pekerja. 


\section{Rumusan masalah}

1. Bagaimana kondisi pekerjaan fabrikasi tulangan di proyek Indonesia 1 ditinjau dari besar waktu tidak produktif serta upah produktif para pekerja dengan menggunakan diagram Crew Balance Chart?

2. Berapa biaya real dan optimal pekerjaan fabrikasi tulangan proyek Indonesia 1 setelah dilakukan analisis produktivitas dengan bantuan diagram Crew Balance Chart?

3. Berapa besar kerugian dari segi biaya yang diakibatkan rendahnya produktivitas para pekerja fabrikasi tulangan proyek Indonesia 1 ?

\section{Tujuan penelitian}

Tujuan dari penulisan skripsi ini adalah untuk menentukan :

1. Kondisi pekerjaan fabrikasi tulangan di proyek Indonesia 1 ditinjau dari waktu tidak produktif dan upah produktif para pekerja.

2. Biaya real dan optimal pekerjaan fabrikasi tulangan proyek Indonesia 1 setelah dilakukan analisis produktivitas dengan bantuan diagram Crew Balance Chart.

3. Besar kerugian dari segi biaya yang diakibatkan rendahnya produktivitas para pekerja fabrikasi tulangan proyek Indonesia 1.

\section{Batasan masalah}

1. Analisis perhitungan biaya berdasarkan pendataan dari lapangan pada pekerjaan fabrikasi proyek Indonesia 1 dengan permodelan diagram Crew Balance Chart

2. Pengamatan difokuskan pada pekerjaan fabrikasi pada proyek Indonesia 1.

3. Analisis akan dilakukan pada data yang sesuai dengan kondisi lapangan pada pekerjaan proyek Indonesia 1.

4. Analisis biaya dengan bantuan permodelan diagram Crew Balance Chart hanya meningkatkan produktivitas dari pekerja, tidak dengan mempercepat waktu penyelesaian pekerjaan.

\section{TINJAUAN PUSTAKA}

\section{Biaya}

Biaya proyek adalah biaya-biaya yang diperlukan untuk tiap pekerjaan dalam menyelesaikan suatu proyek. Secara garis besar biaya proyek dapat dibagi menjadi dua yaitu :

a. Biaya Langsung (direct cost)

Biaya langsung merupakan biaya untuk segala sesuatu yang akan menjadi komponen permanen hasil akhir proyek (Soeharto, 1995).

b. Biaya Tidak Langsung (indirect cost)

Biaya tidak langsung adalah pengeluaran untuk manajemen, supervisi dan pembayaran material serta jasa untuk pengadaan bagian proyek yang tidak akan menjadi instalasi atau produk permanen, tetapi diperlukan dalam rangka proses pembangunan proyek (Soeharto, 1995).

\section{Produktivitas}

Produktivitas secara umum dapat diartikan sebagai tingkat perbandingan antara hasil keluaran (output) dengan memasukkan (input), atau rasio antara hasil produksi dengan total sumber daya yang digunakan (Toni Setiawan, 2012). Pada proyek konstruksi, rasio produktivitas adalah nilai yang diukur selama proses konstruksi, dapat dipisahkan menjadi biaya tenaga kerja, material, uang, metoda dan alat. Sukses dan tidaknya proyek konstruksi tergantung pada efektivitas pengelolaan sumber daya (Ervianto, 2005).

Salah satu contoh teknik pengukuran produktivitas adalah metode time study. Metode time study adalah suatu usaha untuk menentukan lamanya waktu kerja yang dibutuhkan oleh seorang operator untuk menyelesaikan suatu pekerjaan pada tingkat kecepatan kerja yang normal serta lingkungan kerja yang terbaik pada saat itu.

Ada dua macam cara untuk memperoleh data untuk metode time study, yaitu dengan menggunakan stopwatch dan kamera video. Pengamatan melalui video (video recording) lebih populer dalam pengumpulan data lapangan menggunakan metode time study. Salah satu metode time study yang dapat diamati menggunakan video recording adalah Crew Balance Chart Method. 


\section{Crew Balance Chart Method}

Crew balance chart adalah sebuah teknik berbentuk grafis yang digunakan untuk menunjukkan aktivitas yang berlanjut (dengan durasi waktu) dari tenaga kerja individual yang mengerjakan pekerjaan konstruksi yang berulang. Pembentukan crew balance chart diawali dengan pencatatan waktu kerja untuk setiap pekerja dan alat yang digunakan (metode time study). Kemudian, hasil pencatatan data ini digunakan untuk menentukan waktu yang dikonsumsi oleh setiap pekerja dan alat. Penggunaan video kamera selama pencatatan data merupakan alternatif yang patut dipertimbangkan mengingat hal ini dapat menunjukkan aliran pekerja, material, dan alat.

Crew balance chart digambarkan berupa batang vertikal yang merepresentasikan setiap pekerja atau peralatan yang digunakan. Sumbu y (ordinat) melambangkan waktu yang dibutuhkan untuk melaksanakan pekerjaan. Batang vertikal ini dibagi menjadi beberapa bagian yang merepresentasikan subkegiatan, seperti waktu kegiatan, waktu idle, waktu yang tidak efisien, waktu yang tidak produktif. Contoh bentuk diagram crew balance chart dapat dilihat pada gambar 1 .

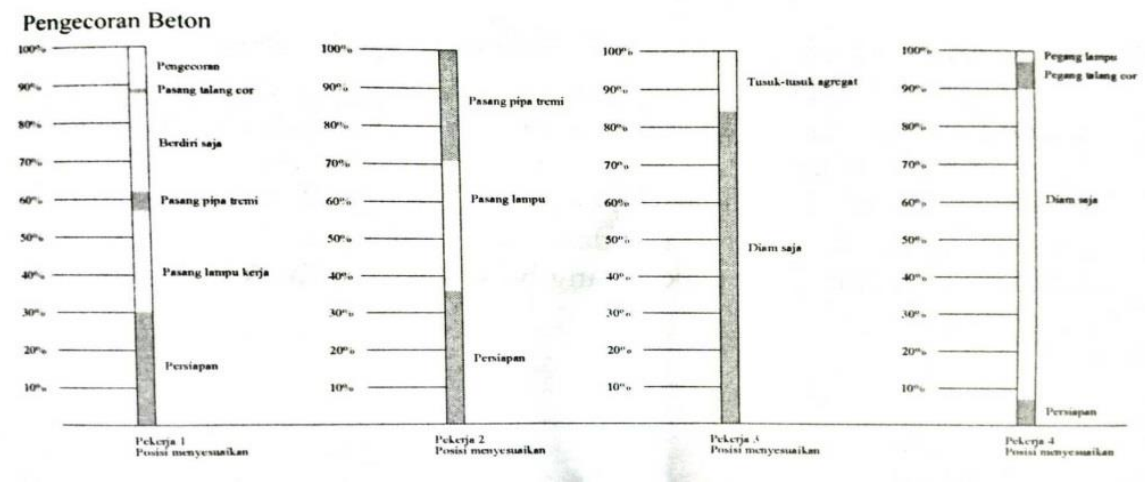

Gambar 1. Crew Balance Chart Pengecoran Beton (Sumber: Ervianto, 2005)

Dari diagram crew balance chart ini akan dihitung perbandingan waktu dasar dengan waktu tidak produktif dari pekerjaan yang bersangkutan. Perbandingan waktu dasar dan waktu tidak produktif ini akan ditampilkan dalam bentuk tabel rekapitulasi pekerjaan pada tabel 2.

Tabel 2. Rekapitulasi Waktu Kegiatan

\begin{tabular}{|c|c|c|c|c|c|c|c|}
\hline \multirow{2}{*}{$\begin{array}{c}\text { Tenaga } \\
\text { kerja }\end{array}$} & \multirow{2}{*}{ Kegiatan } & \multicolumn{3}{|c|}{ Waktu produktif } & \multicolumn{3}{|c|}{ Waktu tidak produktif } \\
\hline & & Observasi & Rata-rata & $\%$ & Observasi & Rata-rata & $\%$ \\
\hline \multirow{6}{*}{$\mathrm{C}$} & \multirow{6}{*}{ Tukang } & $X_{A 1}$ & $X_{A 1}+X_{B 1}$ & \multirow{2}{*}{$Z_{1}$} & $Y_{A 1}$ & $Y_{A 1}+Y_{B 1}$ & \multirow{2}{*}{$Z^{\prime}{ }_{1}$} \\
\hline & & $X_{B 1}$ & $n$ & & $Y_{B 1}$ & $n$ & \\
\hline & & $X_{A 2}$ & $X_{A 2}+X_{B 2}$ & \multirow{2}{*}{$Z_{2}$} & $Y_{A 2}$ & $Y_{A 2}+Y_{B 2}$ & \multirow{2}{*}{$Z^{\prime}{ }_{2}$} \\
\hline & & $X_{B 2}$ & $n$ & & $Y_{B 2}$ & $n$ & \\
\hline & & $X_{A m}$ & $X_{A m}+X_{B m}$ & \multirow{2}{*}{$Z_{m}$} & $Y_{A m}$ & $Y_{A m}+Y_{B m}$ & \multirow{2}{*}{$Z_{m}^{\prime}$} \\
\hline & & $X_{B m}$ & $n$ & & $Y_{B m}$ & $m$ & \\
\hline \multicolumn{3}{|c|}{ Rekapitulasi waktu total } & $\Sigma\left(\frac{X_{A}+X_{B}}{n}\right)$ & $\Sigma \mathrm{Z}$ & & $\Sigma\left(\frac{Y_{A}+Y_{B}}{n}\right)$ & $\Sigma Z^{\prime}$ \\
\hline
\end{tabular}

Keterangan:

$X_{A m}=$ waktu dasar pekerja $\mathrm{C}$ saat jam A pada sub kegiatan m saat observasi

$X_{B m}=$ waktu dasar pekerja $\mathrm{C}$ saat jam B pada sub kegiatan m saat observasi

$Y_{A m}=$ waktu tidak produktif pekerja $\mathrm{C}$ saat jam A pada sub kegiatan $\mathrm{m}$ saat observasi

$Y_{B m}=$ waktu tidak produktif pekerja B saat jam B pada sub kegiatan m saat observasi

$\mathrm{n} \quad$ = rata-rata waktu jam A dan jam B

$Z_{m}=$ persentase waktu produktif 
$Z_{m}^{\prime}=$ persentase waktu tidak produktif

$$
\begin{array}{cc}
Z_{m} & =\frac{\text { waktu produktif rata-rata sub-kegiatan } m}{\text { waktu dasar rata-rata sub-kegiatan } m} \times 100 \% \\
Z_{m}^{\prime} & =\frac{\text { waktu tidak produktif rata-rata sub-kegiatan } m}{\text { waktu dasar rata-rata sub-kegiatan } m} \times 100 \%
\end{array}
$$

\section{METODOLOGI PENELITIAN}

\section{Tempat dan objek penelitian}

Tempat penelitian ini dilakukan adalah proyek Indonesia 1, Jakarta Pusat. Penelitian ini akan menggunakan metode observasi dan wawancara untuk memperoleh data-data yang dibutuhkan. Metode observasi akan difokuskan selama pekerjaan fabrikasi tulangan proyek Indonesia 1 berlangsung dengan menggunakan alat bantu video camera. Wawancara akan dilakukan pada Project Manager dan para pekerja yang terlibat dalam proyek Indonesia 1.

\section{Metode pengolahan data}

Analisis data akan diawali dengan memplot kegiatan dalam pekerjaan dengan menggunakan metode diagram crew balance chart. Diagram crew balance chart akan menampilkan data hasil observasi pada pekerjaan pembesian pada proyek Indonesia 1. Dari diagram ini, maka akan diperoleh persentase waktu produktif dan tidak produktif dari setiap pekerja beserta upah produktif yang sesuai dengan produktivitas dari masing-masing pekerja. Persentase waktu produktif yang didapat dari diagram Crew Balance Chart ini akan digunakan untuk menghitung besaran koefisien produktivitas dari para pekerja.

Besaran koefisien produktivitas yang didapat dari perhitungan ini kemudian akan digunakan dalam tabel analisa harga satuan pekerjaan menurut SNI untuk menghitung besar biaya pekerjaan fabrikasi proyek Indonesia 1. Hasilnya kemudian akan dibandingkan dengan biaya pekerjaan fabrikasi proyek Indonesia 1 yang dihitung berdasarkan koefisien produktivitas standar SNI 7394-2008 dengan memperhitungkan kelonggaran yang terjadi akibat faktor-faktor luar. Dari perbandingan kedua biaya tersebut, maka besar kerugian akibat adanya waktu tidak produktif para pekerja dapat dihitung dengan cara mengurangkan kedua biaya tersebut

\section{ANALISIS DAN PEMBAHASAN}

\section{Hasil pengumpulan data penelitian}

Penelitian produktivitas tenaga kerja pada pekerjaan fabrikasi tulangan pada proyek Indonesia 1, Jakarta dilakukan selama 6 jam dalam kurun waktu 2 hari. Dalam pekerjaan fabrikasi tulangan ini, terdapat 2 kelompok pekerja yang bertanggung jawab untuk 2 kegiatan yang berbeda, yaitu kelompok pekerjaan cutting tulangan dan kelompok pekerjaan bending tulangan.

Data yang diambil pada saat pekerja melaksanakan fabrikasi tulangan adalah merekam dan mencatat waktu produktif dan waktu tidak produktif dari pekerjaan tersebut. Waktu produktif dan tidak produktif ini akan diproses dan dihitung untuk mendapatkan waktu produktivitas tenaga kerja dan mengetahui koefisien tenaga kerja. Pada tabel 2 dapat dilihat contoh rekapitulasi waktu kegiatan dari para pekerja pada jam pertama..

Tabel 2. Contoh Hasil Pengamatan Kondisi Tenaga Kerja

\begin{tabular}{|c|c|c|c|c|}
\hline \multirow{2}{*}{ Waktu } & \multicolumn{4}{|c|}{ Tenaga Kerja } \\
\cline { 2 - 5 } & $\mathrm{A}$ & $\mathrm{B}$ & $\mathrm{C}$ & $\mathrm{D}$ \\
\hline $00.00-01.19$ & prep & idle & idle & idle \\
\hline $01.19-06.26$ & bending & bending & prep & prep \\
\hline $06.26-07.25$ & bending & bending & cutting & cutting \\
\hline $07.25-16.30$ & idle & idle & cutting & cutting \\
\hline $16.30-24.25$ & bending & bending & cutting & cutting \\
\hline $24.25-25.30$ & idle & idle & cutting & cutting \\
\hline $25.30-30.53$ & bending & bending & cutting & cutting \\
\hline
\end{tabular}




\begin{tabular}{|c|c|c|c|c|}
\hline \multirow{2}{*}{ Waktu } & \multicolumn{4}{|c|}{ Tenaga Kerja } \\
\cline { 2 - 5 } & $\mathrm{A}$ & $\mathrm{B}$ & $\mathrm{C}$ & $\mathrm{D}$ \\
\hline $30.53-47.55$ & bending & bending & idle & idle \\
\hline $47.55-48.55$ & idle & idle & idle & idle \\
\hline $48.55-49.43$ & bending & bending & idle & idle \\
\hline $49.43-60.00$ & bending & bending & cutting & cutting \\
\hline
\end{tabular}

Ada berbagai macam kegiatan yang dilakukan pekerja selama waktu pengamatan, yaitu prep, cutting, bending, idle, dan wait. Prep artinya persiapan yang dilakukan pekerja sebelum memulai pekerjaan fabrikasi, seperti mempersiapkan dan mengatur alat, serta mengukur panjang potongan dan bengkokan. Cutting artinya para pekerja sedang melakukan kegiatan pemotongan tulangan. Bending artinya para pekerja sedang melakukan kegiatan pembengkokan tulangan. Idle artinya waktu di mana para pekerja tidak melakukan kegiatan apapun yang berkaitan dengan pekerjaan mereka, seperti mengobrol, minum kopi, dan beristirahat di luar jam makan. Wait artinya para pekerja sedang menunggu hasil potongan tulangan untuk dikerjakan di bagian bending.

\section{Perhitungan dan rekapitulasi}

Perhitungan lengkap dari persentase waktu produktif dan waktu tidak produktif pekerja akan dilakukan menggunakan tabel rekapitulasi kegiatan. Pada tabel 3 dapat dilihat contoh rekapitulasi waktu kegiatan dari pekerja A pada hari pertama yang menampilkan waktu produktif dan waktu tidak produktif dari pekerja A.

Tabel 3. Rekapitulasi Waktu Kegiatan Hari Pertama

\begin{tabular}{|c|c|c|c|c|c|c|c|c|}
\hline \multirow[b]{2}{*}{ Nama } & \multirow[b]{2}{*}{ Kegiatan } & \multirow[b]{2}{*}{ Jam } & \multicolumn{3}{|c|}{ Waktu Produktif } & \multicolumn{3}{|c|}{ Waktu Tidak Produktif } \\
\hline & & & $\begin{array}{c}\text { Observasi } \\
\text { (menit) }\end{array}$ & $\begin{array}{c}\text { Rata-rata } \\
\text { (menit) }\end{array}$ & $\%$ & $\begin{array}{c}\text { Observasi } \\
\text { (menit) }\end{array}$ & $\begin{array}{c}\text { Rata-rata } \\
\text { (menit) }\end{array}$ & $\%$ \\
\hline \multirow{12}{*}{ A } & \multirow{12}{*}{$\begin{array}{l}\text { Bending } \\
\text { tulangan }\end{array}$} & 09.00-09.30 & 19.833 & \multirow{2}{*}{24.4165} & \multirow{2}{*}{13.56} & 10.167 & \multirow{2}{*}{5.5835} & \multirow{2}{*}{3.102} \\
\hline & & 09.30-10.00 & 29 & & & 1 & & \\
\hline & & $10.00-10.30$ & 16.833 & \multirow{2}{*}{13.1665} & \multirow{2}{*}{7.315} & 13.167 & \multirow{2}{*}{16.8335} & \multirow{2}{*}{9.352} \\
\hline & & $10.30-11.00$ & 9.5 & & & 20.5 & & \\
\hline & & $11.00-11.30$ & 9.667 & \multirow{2}{*}{10.5415} & \multirow{2}{*}{5.856} & 20.333 & \multirow{2}{*}{19.4585} & \multirow{2}{*}{10.81} \\
\hline & & $11.30-12.00$ & 11.416 & & & 18.584 & & \\
\hline & & $13.00-13.30$ & 26.883 & \multirow{2}{*}{13.4415} & \multirow{2}{*}{7.468} & 3.117 & \multirow{2}{*}{16.5585} & \multirow{2}{*}{9.199} \\
\hline & & $13.30-14.00$ & 0 & & & 30 & & \\
\hline & & $14.00-14.30$ & 10.466 & \multirow{2}{*}{17.1} & \multirow{2}{*}{9.5} & 19.534 & \multirow{2}{*}{12.9} & \multirow{2}{*}{7.167} \\
\hline & & \begin{tabular}{|l|}
$14.30-15.00$ \\
\end{tabular} & 23.734 & & & 6.266 & & \\
\hline & & $15.00-15.30$ & 21.4 & \multirow{2}{*}{10.7} & \multirow{2}{*}{5.944} & 8.6 & \multirow{2}{*}{19.3} & \multirow{2}{*}{10.72} \\
\hline & & $15.30-16.00$ & 0 & & & 30 & & \\
\hline & & & 178.732 & & 49.65 & 181.268 & & 50.35 \\
\hline
\end{tabular}

Dari tabel 3, diperoleh bahwa besar waktu produktif pekerja A adalah sebesar 49,6478\%, sementara besar waktu tidak produktif dari pekerja A adalah sebesar 50,35\%.

Rekapitulasi waktu tidak produktif pada hari pertama dan kedua dapat dilihat pada tabel 4.

Tabel 4. Rekapitulasi Total Waktu Tidak Produktif Hari Pertama dan Kedua

\begin{tabular}{|c|c|c|c|c|}
\hline \multirow{2}{*}{ No. } & \multirow{2}{*}{ Nama } & \multirow{2}{*}{ Jabatan } & \multicolumn{2}{|c|}{ Persentase total waktu tidak produktif (\%) } \\
\cline { 4 - 5 } & & & Hari pertama & Hari kedua \\
\hline 1. & A & Tukang bending & 50.35 & 48.6 \\
\hline 2. & B & Tukang bending & 51.74 & 54.65 \\
\hline 3. & C & Tukang cutting & 48.76 & 49.47 \\
\hline 4. & D & Tukang cutting & 49.06 & 50 \\
\hline
\end{tabular}




\section{Implementasi Crew Balance Chart}

Data yang diperoleh akan diimplementasikan ke dalam bentuk diagram CrewBalance Chart. Pada gambar 2, dapat dilihat contoh diagram crew balance chart dari seluruh pekerja pada hari pertama.

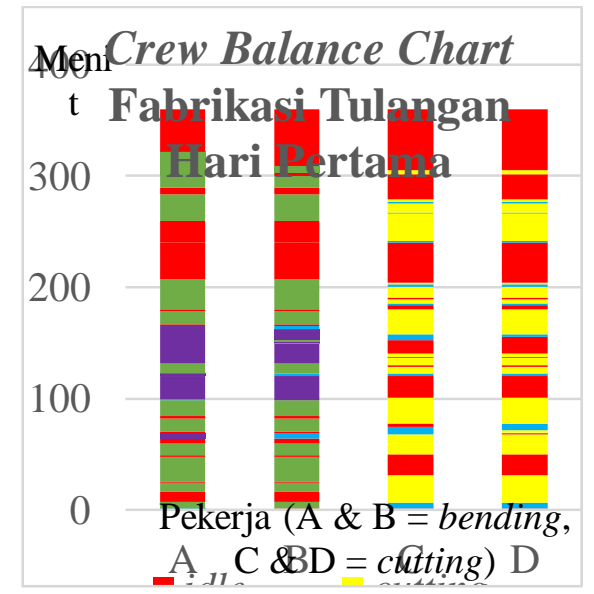

Gambar 2. Crew Balance Chart Fabrikasi Tulangan Hari Pertama

Keterangan :

$\begin{array}{ll}\text { Idle } & =\text { waktu tidak produktif (mengobrol, bersantai, minum kopi) } \\ \text { Bending } & =\text { kegiatan pembengkokan tulangan } \\ \text { Cutting } & =\text { kegiatan pemotongan tulangan } \\ \text { Prep } & =\text { persiapan alat, pengukuran panjang potongan tulangan } \\ \text { Wait } & =\text { menunggu suplai tulangan yang akan dikerjakan tersedia }\end{array}$

\section{Analisis pembayaran upah kerja}

Berdasarkan seluruh data yang telah diperoleh dan dihitung melalui tabel rekapitulasi waktu kegiatan, maka pada tabel 5 dan 6 dapat dilihat rekapitulasi upah seluruh pekerja pada hari pertama dan kedua.

Tabel 5. Rekapitulasi Hasil Perhitungan Upah Pekerja Hari Pertama

\begin{tabular}{|c|c|c|c|}
\hline \multirow{2}{*}{ KOEFISIEN (\%) } & \multirow{2}{*}{ JABATAN } & SATUAN & \multirow{2}{*}{ JUMLAH } \\
\cline { 3 - 3 } & & HARGA/HARI & \\
\hline 49.6478 & PEKERJA A & 90.000 & 44.683 \\
\hline 48.1528 & PEKERJA B & 90.000 & $43.437,5$ \\
\hline 51.2408 & PEKERJA C & 90.000 & $46.116,75$ \\
\hline 50.9353 & PEKERJA D & 90.000 & $45.841,75$ \\
\hline
\end{tabular}

Tabel 6. Rekapitulasi Hasil Perhitungan Upah Pekerja Hari Kedua

\begin{tabular}{|c|c|c|c|}
\hline \multirow{2}{*}{ KOEFISIEN (\%) } & \multirow{2}{*}{ JABATAN } & SATUAN & \multirow{2}{*}{ JUMLAH } \\
\cline { 3 - 3 } & & HARGA/HARI & \\
\hline 51.3983 & PEKERJA A & 90.000 & $46.258,5$ \\
\hline 45.3517 & PEKERJA B & 90.000 & $40.816,5$ \\
\hline 50.5278 & PEKERJA C & 90.000 & 45.475 \\
\hline 50 & PEKERJA D & 90.000 & 45.000 \\
\hline
\end{tabular}




\section{Analisis produktivitas pekerja}

Perhitungan didapat dengan mengalikan hasil fabrikasi dengan berat potongan tulangan yang dikerjakan. Jumlah dan berat tulangan yang dikerjakan beragam, tergantung dari panjang potongan dan diameter tulangan yang dikerjakan di lapangan.

a. Hari pertama

Produktivitas total :

$=\Sigma($ Jumlah hasil bending $\mathrm{x}$ berat potongan tulangan $)$

$=(162 \times 0,814)+(12 \times 5,9095)+(32 \times 8,374)+(24 \times 3,239)+(64 \times 2,8392)+((32+208) \times 1,0192)+(16 \times$

$1,248)+((24+57) \times 6,4064)$

$=1.516,6862 \mathrm{~kg}$

b. Hari kedua

Produktivitas total :

$=\Sigma$ (Jumlah hasil bending $\mathrm{x}$ berat potongan tulangan $)$

$=((48+43+27+51+18 \times 3,1408)+(5 \times 1,0192)+(279 \times 1,248)+(21 \times 6,4064)+(17 \times 5,9095)$

$=1.175,6135 \mathrm{~kg}$

Total produktivitas fabrikasi tulangan $=1.516,6862+1.175,6135=\mathbf{2 . 6 9 2 , 2 9 9 7} \mathbf{~ k g}$

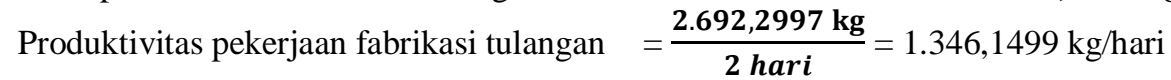

\section{Perhitungan koefisien produktivitas pekerjaan fabrikasi tulangan}

Tabel 6. Rekapitulasi Waktu Produktif Rata-rata Pekerja

\begin{tabular}{|c|c|c|c|}
\hline Pekerja & $\begin{array}{c}\text { Waktu produktif } \\
\text { hari pertama }(\%)\end{array}$ & $\begin{array}{c}\text { Waktu produktif } \\
\text { hari kedua }(\%)\end{array}$ & $\begin{array}{c}\text { Waktu produktif } \\
\text { rata-rata }(\%)\end{array}$ \\
\hline A & 49,6478 & 51,3983 & 50,5231 \\
\hline B & 48,2639 & 45,3517 & 46,8078 \\
\hline C & 51,2408 & 50,5278 & 50,8843 \\
\hline D & 50,9353 & 50 & 50,4677 \\
\hline
\end{tabular}

Koefisien waktu produktif pekerja cutting:

$=$ rata-rata koefisien waktu produktif pekerja $\mathrm{C}$ dan $\mathrm{D}=\frac{(50,8843 \%+50,4677 \%)}{2}=50,676 \%$

Koefisien waktu produktif pekerja bending:

$=$ rata-rata koefisien waktu produktif pekerja $\mathrm{A}$ dan $\mathrm{B}=\frac{(50,5231 \%+46,8078 \%)}{2}=48,6655 \%$

Menurut tabel analisa harga satuan pekerjaan pembesian pada SNI 7394-2008, besar koefisien produktivitas pekerja dan tukang besi adalah sebesar 0,07.

Koefisien produktivitas pekerja cutting $\quad=50,676 \% \times 0,07=0,0355$

Koefisien produktivitas pekerja bending $\quad=48,6655 \% \times 0,07=0,03407$

\section{Pemakaian hasil pengamatan dalam analisa harga satuan}

1. Fabrikasi $10 \mathrm{~kg}$ dengan Besi Polos/Beli Ulir dengan Kelonggaran untuk Produktivitas Pekerja

Berdasarkan kondisi lapangan, besar kelonggaran untuk produktivitas yang diberikan adalah sebesar :

Bekerja di meja, berdiri

Berdiri di atas dua kaki

Gerakan normal

Pandangan terputus-putus dengan pencahayaan baik

Keadaan temperatur tempat kerja tinggi

Keadaan atmosfir baik

Keadaan lingkungan sangat bising

$$
\begin{aligned}
& =6 \% \\
& =1 \% \\
& =0 \% \\
& =0 \% \\
& =5 \% \\
& =0 \% \\
& =2 \%
\end{aligned}
$$


Kebutuhan pribadi pria $=1 \%+$

Total $=15 \%$

Menurut tabel analisa harga satuan pekerjaan pembesian pada SNI 7394-2008, besar koefisien produktivitas pekerja dan tukang besi adalah sebesar 0,07. Maka, besar koefisien produktivitas yang akan dipakai dalam perhitungan adalah $=(100-15) \%$ × 0,07 $=0,0595$. Koefisien ini akan diperhitungkan sebagai koefisien produktivitas pekerja dan tukang besi dalam analisa upah tenaga kerja pada tabel 7.

Tabel 7. Perhitungan Analisa Harga Satuan Pekerjaan Fabrikasi Tulangan Dengan Memperhitungkan Kelonggaran Pekerja

\begin{tabular}{|c|c|c|c|c|}
\hline No. & Uraian & Koefisien & $\begin{array}{c}\text { Harga } \\
\text { satuan (Rp) }\end{array}$ & $\begin{array}{c}\text { Jumlah } \\
\text { Harga (Rp) }\end{array}$ \\
\hline \multirow{6}{*}{ A. } & TENAGA KERJA & & & \\
\hline & Pekerja & 0,0595 & 90.000 & 5.355 \\
\hline & Tukang Besi & 0,0595 & 90.000 & 5.355 \\
\hline & Kepala Tukang & 0,007 & 110.000 & 770 \\
\hline & Mandor & 0,004 & 105.000 & 420 \\
\hline & \multicolumn{3}{|c|}{ Total } & 11.900 \\
\hline \multirow{4}{*}{ B. } & BAHAN & & & \\
\hline & $\begin{array}{l}\text { Besi beton } \\
\text { (polos/ulir) }\end{array}$ & 10,5 & 8.000 & 84.000 \\
\hline & Kawat beton & 0,1 & 15.000 & 1.500 \\
\hline & \multicolumn{3}{|c|}{ Total } & 85.500 \\
\hline C. & \multicolumn{3}{|l|}{ Jumlah $(\mathrm{A}+\mathrm{B})$} & 97.400 \\
\hline D. & Overhead \& Profit & $5 \%)$ & $15 \% \times \mathrm{D}$ & 14.610 \\
\hline E. & \multicolumn{3}{|c|}{ Harga Satuan Pekerjaan (D+E) } & 112.010 \\
\hline
\end{tabular}

Biaya pekerjaan fabrikasi $=$ Jumlah hasil fabrikasi $\mathrm{x}$ Harga satuan pekerjaan $=2.692,2997 \times \mathrm{Rp} 112.010=$ Rp 301.564.489,40

2. Fabrikasi $10 \mathrm{~kg}$ dengan Besi Polos/Besi Ulir Berdasarkan Produktivitas Pekerja

Berdasarkan hasil perhitungan sebelumnya, didapat bahwa koefisien produktivitas pekerja fabrikasi tulangan proyek Indonesia 1 untuk bagian bending dan cutting adalah 0,0355 dan 0,0341. Besar koefisien produktivitas pekerja ini akan diperhitungkan ke dalam tabel analisa harga satuan pekerjaan dan hasilnya dapat dilihat melalui tabel 8 .

Tabel 8. Perhitungan Analisa Harga Satuan Pekerjaan Fabrikasi Tulangan Menurut Produktivitas Pekerja

\begin{tabular}{|c|c|c|c|c|}
\hline No. & Uraian & Koefisien & $\begin{array}{c}\text { Harga } \\
\text { satuan (Rp) }\end{array}$ & $\begin{array}{c}\text { Jumlah } \\
\text { Harga (Rp) }\end{array}$ \\
\hline \multirow{6}{*}{ A. } & TENAGA KERJA & & & \\
\hline & Pekerja & 0,0355 & 90.000 & 3.195 \\
\hline & Tukang Besi & 0,0341 & 90.000 & 3.069 \\
\hline & Kepala Tukang & 0,007 & 110.000 & 770 \\
\hline & Mandor & 0,004 & 105.000 & 420 \\
\hline & \multicolumn{3}{|c|}{ Total } & 7.454 \\
\hline \multirow{4}{*}{ B. } & BAHAN & & & \\
\hline & $\begin{array}{l}\text { Besi beton } \\
\text { (polos/ulir) }\end{array}$ & 10,5 & 8.000 & 84.000 \\
\hline & Kawat beton & 0,1 & 15.000 & 1.500 \\
\hline & \multicolumn{3}{|c|}{ Total } & 85.500 \\
\hline C. & \multicolumn{3}{|l|}{ Jumlah $(\mathrm{A}+\mathrm{B})$} & 92.954 \\
\hline D. & \multicolumn{2}{|c|}{ Overhead \& Profit $(15 \%)$} & $15 \% \times \mathrm{D}$ & $13.943,10$ \\
\hline E. & \multicolumn{3}{|c|}{ Harga Satuan Pekerjaan $(\mathrm{D}+\mathrm{E})$} & $106.897,10$ \\
\hline
\end{tabular}

Biaya pekerjaan fabrikasi = Jumlah hasil fabrikasi x Harga satuan pekerjaan $=2.692,2997 \times \operatorname{Rp} 106.897,10$ 
$=$ Rp 287.799.030,30

\section{Analisis kerugian kontraktor}

Berikut ini akan dihitung besar kerugian yang dibayarkan kontraktor akibat adanya waktu tidak produktif dari para pekerja selama pekerjaan fabrikasi tulangan berlangsung.

Besar kerugian kontraktor :

= Biaya pekerjaan fabrikasi dengan kelonggaran pekerja - biaya pekerjaan fabrikasi sesuai produktivitas

$=\operatorname{Rp} 301.564 .489,40-\operatorname{Rp} 287.799 .030,26$

$=\operatorname{Rp} 13.765 .459,14$

\section{PENUTUP}

\section{Kesimpulan}

Berdasarkan analisis dan hasil perhitungan dari data-data yang didapat melalui penelitian ini, maka dapat disimpulkan bahwa :

1. Berdasarkan penelitian menggunakan diagram crew balance chart, dapat diketahui bahwa persentase (\%) waktu tidak produktif dan upah produktif pada setiap pekerja adalah sebagai berikut :

a. Pekerja A (tukang bending)

Hari pertama $=50.35 \%$ dengan upah produktif Rp $44.683 / \mathrm{kg}$

Hari kedua $=48.6 \%$ dengan upah produktif $\mathrm{Rp} 46.258,5 / \mathrm{kg}$

b. Pekerja B (tukang bending)

Hari pertama $=51.74 \%$ dengan upah produktif Rp 43.437,5/kg

Hari kedua $=54.65 \%$ dengan upah produktif $\mathrm{Rp} 40.816,5 / \mathrm{kg}$

c. Pekerja C (tukang cutting)

Hari pertama $=48.76 \%$ dengan upah produktif Rp $46.116,75 / \mathrm{kg}$

Hari kedua $=49.47 \%$ dengan upah produktif $\mathrm{Rp} 45.475 / \mathrm{kg}$

d. Pekerja D (tukang cutting)

Hari pertama $=49.06 \%$ dengan upah produktif Rp $45.841,75 / \mathrm{kg}$

Hari kedua $=50 \%$ dengan upah produktif $\mathrm{Rp} 45.000 / \mathrm{kg}$

Dari besaran persentase waktu tidak produktif dan upah produktif masing-masing pekerja yang ada, dapat dilihat bahwa jumlah waktu tidak produktif yang ada cukup besar, sehingga dapat disimpulkan bahwa pekerjaan fabrikasi tulangan pada proyek Indonesia 1 ini kurang baik dan kurang efisien.

2. Berdasarkan analisa harga satuan pekerjaan menurut SNI 7394-2008 dan memperhitungkan kelonggaran pekerja, diperoleh bahwa biaya pekerjaan fabrikasi tulangan pada proyek Indonesia 1 adalah sebesar $\mathrm{Rp}$ 301.564.489,40. Sementara itu, biaya pekerjaan fabrikasi tulangan sesuai dengan produktivitas pekerja adalah sebesar Rp 287.799.030,26.

3. Besar kerugian kontraktor akibat kurangnya produktivitas pekerja selama pelaksanaan pekerjaan fabrikasi tulangan pada proyek Indonesia 1 adalah Rp 13.765.459,14.

\section{Saran}

1. Penambahan mandor diperlukan pada proyek ini agar pengawasan terhadap para pekerja lebih ketat. Dengan adanya pengawasan terhadap para pekerja ini, waktu tidak produktif dari para pekerja dapat berkurang sehingga para pekerja menjadi lebih produktif dalam melaksanakan tanggung jawabnya.

2. Koefisien produktivitas standar SNI sebaiknya ditinjau ulang agar koefisien tersebut sesuai dengan produktivitas real para pekerja di lapangan. Dengan demikian, hasil perhitungan biaya pekerjaan bersangkutan akan berkurang dan pemborosan biaya pekerjaan dapat dikurangi.

3. Pengamatan (observasi) untuk penelitian selanjutnya terhadap pekerjaan diharapkan dapat dilakukan dalam durasi waktu (hari) yang lebih lama dan pada objek pekerjaan lain yang berskala lebih besar serta melibatkan banyak tenaga kerja, sehingga pengaruh produktivitas terhadap biaya pekerjaan dapat lebih terlihat dan hasil yang lebih optimal lebih mudah diperoleh. 


\section{DAFTAR PUSTAKA}

Badan Standarisasi Nasional. RSNI 7394:2008 Tata Cara Perhitungan Harga Satuan Pekerjaan Beton Untuk Konstruksi Bangunan dan Perumahan. Jakarta: BSN, 2008.

Ervianto, W.I. Manajemen Proyek Konstruksi: Edisi Revisi. Yogyakarta: Penerbit Andi, 2005.

Kuprenas, J.A. dan Fakhouri A.S. Jurnal Crew Balance Case Study - Improving Construction Productivity. Construction Management Association of America. 2001.

Oglesby, C.H.; Parker, H.W.; dan Howell, G.A. Productivity Improvement In Construction. New York: McGrawHill, Inc., 1989.

Slamet, Edi, et. al. Jurnal Pengamatan Produktivitas Pekerjaan Pengecoran Menggunakan Concrete Pump Dengan Metode Time Studies Beserta Peningkatan Produktivitasnya. Fakultas Teknik Sipil dan Lingkungan Institut Teknologi Bandung. 2005.

Soeharto, I. Manajemen Proyek, Dari Konseptual sampai Operasional, Edisi Kedua Jilid 2. Jakarta: Penerbit Erlangga. 2001. 